\title{
Comparison of Education Based on Genders- A Relevant Study
}

\author{
Kaouther Znaidi ${ }^{1}$, Almas Sabir ${ }^{2}$ \\ ${ }^{1,2}$ College of Business Administration, Department Management, University of Hail, Kingdom of Saudi Arabia \\ almas.sabir083@gmail.com
}

\begin{abstract}
India's improved education framework is frequently referred to as one of the principal supporters of its monetary advancement. A great part of the advancement, particularly in advanced education and logical research, has been credited to different open foundations. In this article we will examine our survey in detail that was conducted by a team of 5 employees who reviewed about education level of guys and females. In the wake of dissecting all variables, we will see the rate level of education in both the sexes. The paper looks at the issue of ladies' entrance to education in India. Drawing on existing writing and different measurements concerning education, the paper gives a review of the condition of instruction as for ladies and features a portion of the issues what's more, hindrances to ladies' education. In light of an investigation of new issues, a few proposals and recommendations are offered as far as grassroots level intercessions, key activities and empowering arrangement system, towards improving ladies' entrance to education.
\end{abstract}

Keywords: Education; genders; comparison.

\section{Introduction}

Education is the main impetus of social orders. Its need or complete nonattendance is hazardous for the entire world. Anyway, even with understanding its significance, a few people go on with denying young ladies an opportunity to learn. I generally wonder why young ladies? For what reason don't individuals comprehend that sexual orientation hole in each part of life prevents the elements of the general public. Anyway, the issue still exists and it will require some investment to conquer it and evacuate the results. With no entrance to instruction, ladies become feeble. At that point, different issues appear. States become flimsier because it's difficult to depend on men's control as it were. India is home to more than 1 billion individuals in this manner, takes the second place on the planet. In any case, regarding ignorance level, it's on the lead. This is very pathetic. Female training in India is in urgent circumstances. Insights close by with figures demonstrate that there is as yet an enormous hole in young ladies' and young men's instruction in India to be filled.

The different insights and various examinations have more than once indicated the need to broaden the span and access of educational training to the ladies of the nation. Despite the fact that educations rates what's more, access to instruction are a region of worry for the twoguys and females, they show up especially dangerous for ladies. The dropout rates and enrolment in advanced education infer that getting young ladies to take a crack at schools is the principal obstacle when surmounted young ladies are more probable than young men to remain on for essential training, yet represent a test again at the optional and more elevated amount of instruction. Despite the fact that it is very much recognized that when you teach a lady you instruct a country, this frequently cited saying has by one way or another been lost in interpretation as the truth of ladies' instruction in India appears to propose[1].

\section{Literature Review}

Ladies keep on enduring types of segregation in numerous nations over the globe, including kid and constrained marriage, sexual orientation-based viciousness, misogynist 
approaches, just as obstructions to interest in instruction and work[2] Accomplishing sexual orientation balance universally is urgent to meeting advancement objectives, decreasing human misery and taking care of our greatest natural issues.

\subsection{Obstructions to Equality}

In most, if not all, nations, ladies don't have as much control as men. They are burdened in numerous ways, including getting to training and business openings, and in their capacity to control their richness, sexual wellbeing, and security from damage [2].

Customs of kid marriage abuse human rights, cause gigantic misery and lessen open doors for instruction, self-governance and a conventional personal satisfaction [2]. Early marriage likewise prompts bigger families and brings a more serious danger of maternal passing and damage identified with labor.

Male centric cultural standards imply that a lady's capacity to decide the number and dispersing of youngsters are constrained or non-existent.

Indeed, even in many created nations, ladies frequently get paid not as much as men for similar employments, face sexual orientation based segregation and viciousness, and experience the ill effects of sexist frames of mind and misogynist approaches that confine their independence over their very own bodies.

According to one research [3] Ms.Nisha Nair said, for what reason do the measurements mirroring ladies' proficiency, their enrolment in essential, optional and advanced education or their dropout rates read so inadequately? What do they delineate for us?

Ladies' entrance to education? What fundamental mistakes have supported this and what should be possible to cure the circumstance? This segment features a portion of the hindrances to ladies' training, drawing on past investigations where conceivable [3]. Ladies and young ladies get far less instruction than men, because of winning social standards and here and their fears of brutality. Indicating the hindrances guardians feel, particularly among poor people or in reverse areas of society, Sonalde Desai, in her book on Gender Inequalities and Demographic Behavior, contends that 'another disincentive for sending little girls to class is a worry for the insurance of their virginity [4]. At the point when schools have situated a ways off, when educators are male, and when young ladies are required to think about alongside young men, guardians are regularly reluctant to open their little girls to the potential strike on their virginity [4].

\subsection{Being Educated Is Not A Privilege: It's A Need}

Instruction as an essential human right is of more noteworthy significance. In like manner, everybody must have an entrance to it with no limitation. Besides, states are to ensure and secure the common ideal for the instruction of its natives [1]. Any infringement ought to be carefully censured. In any case, world practice demonstrates that individuals think little of the job of training, particularly for a young lady [1]. Truth be told, such an approach ought to be exiled because any interest in a young lady's instruction gives more returns.

\subsection{Considering how? Here is the thing that the World Bank has discovered.}

As per its examination, the social effect of taught ladies is valueless. As a matter of first importance taught moms to advance their kids' training also. That makes the general public 
progressively solid and flexible. Other than wise ladies make a superior monetary condition particularly in the nations with a center pay rate. What's more, to wrap things up, such ladies are bound to prevail in the work market and seek after their profession. Truth be told, young lady's education is urgent to taking care of numerous issues both in economies and social orders [1]. It gives a superior life to mankind. The absence of female instruction can just keep the world from further improvements. This is the reason training isn't something to spend too much on [1]. It's an essential human need that must be fulfilled.

Notwithstanding every one of these issues, the Indian government executes different changes to improve the nature of female instruction in India [1].

Yet, before that everybody should begin from his own home. There is some straightforward day by day estimates which will add to ladies' instruction in India. So female training in India can be viewed as improved if:

a. Young ladies are treated as complete individuals from the family

b. The capacities she holds is invited

c. Everybody comprehends that young ladies are not just for ordinary drudgery

d. The significance of female instruction in India is given need

e. Society doesn't limit profession open doors for ladies

f. Abusive behavior at home is canceled and young ladies don't need to drop out the school since they need to wed in token of customs

g. Society individuals comprehend the significant job an informed lady plays in their state

As you see my rundown isn't about cash, spending or terrible stuff. It shares the mentality and disposition of everyday citizens towards female instruction in India. It is vital that something has changed [1].

\subsection{Recent Researches and Their Findings}

The point of this research is to discover the director's job in actualizing quality instruction the board in grade school (SDN) GunungKeling, Meureubo area, Aceh Barat Regency, to discover what imperatives the chief faces in executing quality administration of training in elementary school (SDN) GunungKeling, Meureubo locale, Aceh Barat regime. The examination utilized a subjective methodology. This sort of Research is enlightening (illustrative research). [5]Research time is from August 8 to 27, 2018. His information accumulation strategies, for example, perception techniques, talk with techniques and documentation strategies. [5] The exploration information to be broken down in this investigation is the job of the superintendent in executing training quality administration in grade school of GunungKeling, Meureubo area, Aceh Barat rule, in particular: the job of the dean as Educator, Manager, Administrator, Supervisor, Leader, and Motivator. What snags looked by dean in actualizing training quality administration in grade school region, Aceh Barat rule, seen from the consequences of the examination are:to conquered the obstructions to improving instructor quality did is to persistently do correspondence and Instructive quality culture battles for educators who are still low on mindfulness and in beating the absence of school personnel for changeless subjects, the school demands educators to work through the Aceh Barat area Education Office irrespective of their genders. [5]

The proposals that can be given are as per the following: [6]

a. to the Head of Madrasah to improve the assessment of understudy learning results by observing each adjustment in appraisal exercises from the administration, and alluding 
to the guidelines that have been readied, offices and offices for assessing understudy learning results regarding all matters for the two educational plans,

b. The educator ought to assess the understudy learning results more for the structure, usage, and follow-up in evaluating understudy learning results. Furthermore,

c. The Ministry of Religion in Medan ought to improve educator skill in helping out an appraisal of learning results through preparing exercises, workshops, and workshops [6].In this research also, researcher tries to adopt new educational methods, learning results for women and men

Another aspect of the present study was to examine possible gender differences in the constructs. Although some studies examined gender differences in life satisfaction, they found that there was none (e.g. Diener\&Diener, 1995; Froh, Yurkewicz, \&Kashdan, 2008). Previous research indicates that there are differences between men and women in their emotional awareness and emotional expression (which may influence positive affectivity), level of selfesteem, coping styles, and dispositional gratitude. Among others, Barrett, Lane, Sechrest, and Schwartz (2000) and Ciarrochi, Hynes, and Crittenden (2005) demonstrated that women are more aware of their emotions than men. Kring and Gordon (1998) and Timmers, Fischer, and Monstead (1998) showed that women tend to be more emotionally expressive than men. Kling, Hyde, Showers, and Buswell (1999) performed a meta-analysis representing over 97,000 respondents, and they found that generally men reported higher levels of self-esteem.[7] Matud (2004) found that men tend to use problem solving coping styles, while women use more emotion-focused coping styles. Women may also tend to experience and express more appreciation than men. Indeed, Kashdan et al. (2009) reported that women had significantly higher scores than men on a measure of dispositional gratitude and also derived greater benefits from experiencing and expressing gratitude.[7]

These discoveries are applicable to the flow explore in light of the fact that we asked members to react to proportions of their positive affectivity, confidence, adapting abilities, and their degrees of appreciation. Given that there have all the earmarks of being contrasts in how people involvement and express feelings, it is conceivable (if not likely) that these distinctions would influence the reactions of members and make it hard to make inferences from the discoveries. For instance, if ladies will, in general, be more in contact with and expressive of their feelings, they may will, in general, be more mindful of positive passionate encounters than men - which would influence their reactions on the measure of positive affectivity. Consequently, we controlled for sexual orientation in the present investigation so as to determine the extraordinary commitments of the factors on life fulfillment well beyond any contrasts that might be credited to sexual orientation. [7].

\section{Research Method}

Step 1: Methodological approach: Quantitative method is used in the form of surveys that are best for measuring, identifying patterns and making generalizations.

The survey consisted of 5 multiple-choice questions and 8 questions that the respondents had to answer with a 5-point Likert scale. The aim was to conduct the survey with 200 males and females. Participants were given few minutes to fill in the survey anonymously, and all 200 responded. 


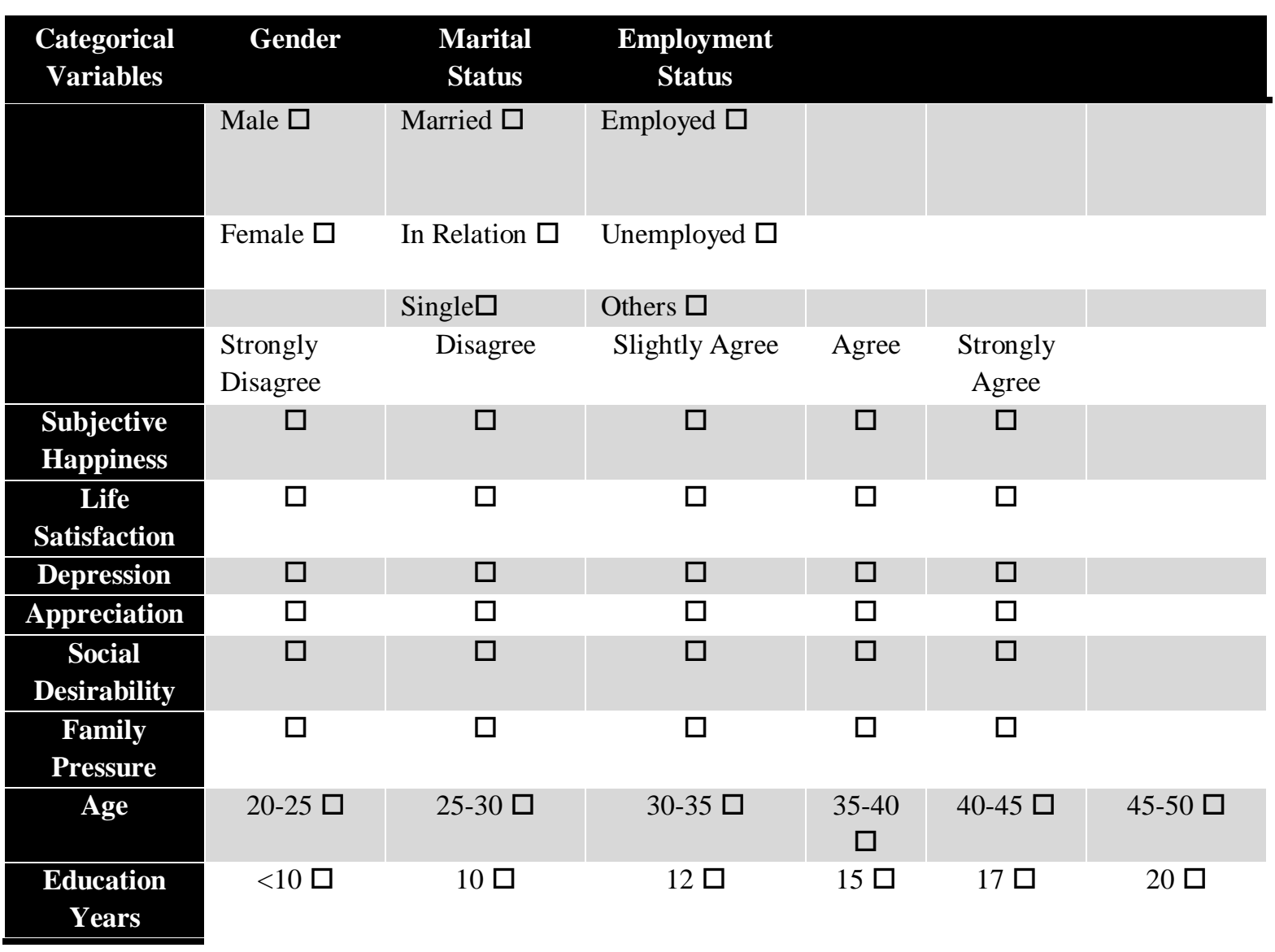

Step 2: Methods of data collection:

1. Sample collected from the place-MayurVihar-Phase-III

2. Sample collected duration: 2Augest-6 August (2019)

3. Conducting of survey: In person (Males-100 and Females-100)

4. Sample size-200

5. Sample response-200

Step 3: Methods of analysis: Before analysis the gathered data was prepared. The dataset was checked for missing data and outliers. The data was then analyzed using statistical software SPSS.CHISQ PHI test is used.The Chi-square test is planned to test how likely it is that an observed distribution is due to chance. It is additionally called an "integrity of fit" measurement since it gauges how well the watched dissemination of information fits with the circulation that is normal if the variables are independent.

Step 4: Evaluatuation and justification of methodological choices CROSSTABS

/TABLES=Gender BY Education

/FORMAT=AVALUE TABLES

/STATISTICS $=$ CHISQ PHI

/CELLS=COUNT EXPECTED ROW /COUNT ROUND CELL. 
Table 1. Case Processing Summary

\begin{tabular}{|c|c|c|c|c|c|c|}
\hline \multirow{2}{*}{} & \multicolumn{6}{|c|}{ Cases } \\
\cline { 2 - 7 } & \multicolumn{2}{|c|}{ Valid } & \multicolumn{2}{c|}{ Missing } & \multicolumn{2}{c|}{ Total } \\
\cline { 2 - 7 } & $\mathrm{N}$ & Percent & $\mathrm{N}$ & Percent & $\mathrm{N}$ & Percent \\
\hline $\begin{array}{c}\text { Gender } * \\
\text { Education }\end{array}$ & 200 & $100.0 \%$ & 0 & $0.0 \%$ & 200 & $100.0 \%$ \\
\hline
\end{tabular}

Table 2. Gender * Education Cross tabulation

\begin{tabular}{|c|c|c|c|c|c|}
\hline & \multicolumn{2}{|c|}{ Education } & \multirow{2}{*}{ Total } \\
\hline & & & Educated & Uneducated & \\
\hline \multirow[t]{6}{*}{ Gender } & \multirow[t]{3}{*}{ Males } & Count & 35 & 65 & 100 \\
\hline & & Expected Count & 27.5 & 72.5 & 100.0 \\
\hline & & $\%$ within Gender & $35.0 \%$ & $65.0 \%$ & $\begin{array}{c}100.0 \\
\%\end{array}$ \\
\hline & \multirow[t]{3}{*}{ Females } & Count & 20 & 80 & 100 \\
\hline & & Expected Count & 27.5 & 72.5 & 100.0 \\
\hline & & $\%$ within Gender & $20.0 \%$ & $80.0 \%$ & $\begin{array}{c}100.0 \\
\%\end{array}$ \\
\hline \multirow{3}{*}{\multicolumn{2}{|c|}{ Total }} & Count & 55 & 145 & 200 \\
\hline & & Expected Count & 55.0 & 145.0 & 200.0 \\
\hline & & $\%$ within Gender & $27.5 \%$ & $72.5 \%$ & $\begin{array}{c}100.0 \\
\%\end{array}$ \\
\hline
\end{tabular}

Table 3. Chi-Square Tests

\begin{tabular}{|l|c|c|c|c|c|}
\hline & Value & df & $\begin{array}{c}\text { Asymptotic } \\
\text { Significance } \\
(2 \text {-sided })\end{array}$ & $\begin{array}{c}\text { Exact Sig. } \\
\text { (2-sided) }\end{array}$ & $\begin{array}{c}\text { Exact Sig. } \\
\text { (1-sided) }\end{array}$ \\
\hline Pearson Chi-Square & $5.643^{\mathrm{a}}$ & 1 & 0.018 & & \\
\hline Continuity Correction & 4.915 & 1 & 0.027 & & \\
\hline Likelihood Ratio & 5.698 & 1 & 0.017 & & 0.013 \\
\hline Fisher's Exact Test & & & & 0.026 & \\
\hline $\begin{array}{l}\text { Linear-by-Linear } \\
\text { Association }\end{array}$ & 5.614 & 1 & 0.018 & & \\
\hline N of Valid Cases & 200 & & & & \\
\hline
\end{tabular}

a. 0 cells $(0.0 \%)$ have expected count less than 5 . The minimum expected count is 27.50 . 
b. Computed only for a $2 \times 2$ table

Table 4. Symmetric Measures

\begin{tabular}{|l|l|c|c|}
\hline \multicolumn{2}{|c|}{} & Value & $\begin{array}{c}\text { Approximate } \\
\text { Significance }\end{array}$ \\
\hline \multirow{2}{*}{ Nominal by Nominal } & Phi & 0.168 & 0.018 \\
\cline { 2 - 4 } & Cramer's V & 0.168 & 0.018 \\
\hline N of Valid Cases & 200 & \\
\hline
\end{tabular}

\section{Results}

We used Chi-Square test of independence in our analysis because it is used to determine and check whether there is any significant relationship between two nominal (categorical) variables. The chi-square test of independence can be used to examine the relationship.

The null hypothesis for this test is that there is a relationship between gender and education here.

There is significant relationship between gender and education, $\left(\chi^{2}\right)(1, N=200)=$ $5.643^{\mathrm{a}}$ and $\mathrm{p}=0.018$ (Asymptotic Significance (2-sided)

\section{Men Were More Likely to Engage in Education Then Women (35\% To 20\%)}

Effect Size: Effect size is a factual idea that estimates the quality of the connection between two factors on a numeric scale.

Cramer's V- It is a way of calculating correlation in tables which have more than $2 \times 2$ rows and columns. It is used as post-test to determine strengths of association after chi-square has determined significance.

We reviewed two different measures of effect size: Phi $\varphi$ and Cramer's $V$ Phi $\varphi$ For the goodness of fit in $2 \times 2$ contingency tables, phi, which is equivalent to the correlation coefficient $r$, is a measure of effect size. Phi is defined by-

Where $n=$ the number of observations. A value of .10 is considered a small effect, $.30 \mathrm{a}$ medium effect and .50 a large effect.

Where $d f^{*}=\min (r-1, c-1)$ and $r=$ number of rows and $c=$ number of columns in the contingency table. In table: 4 , Phi and Cramer's values are 0.168 which is less than medium (.30) and more than small (.10).Hence, Cramer's V is (.20) and as a result of this small effect size is showing in this study.

\begin{tabular}{|c|lccccc|}
\hline S.No & \multicolumn{1}{|c}{ Questions } & $\begin{array}{c}\text { Overall Final Analysis } \\
\text { Strongly } \\
\text { Disagree }\end{array}$ & Disagree & $\begin{array}{c}\text { Slightly } \\
\text { Agree }\end{array}$ & Agree & $\begin{array}{c}\text { Strongly } \\
\text { Agree }\end{array}$ \\
\hline 1. & Subjective Happiness & 10 & 80 & 10 & 40 & 60 \\
\hline 2. & Life Satisfaction & 60 & 30 & 45 & 55 & 10 \\
\hline 3. & Depression & 40 & 50 & 45 & 35 & 30 \\
\hline 4. & Appreciation & 65 & 45 & 25 & 35 & 30 \\
\hline 5. & Social Desirability & 20 & 30 & 40 & 60 & 50 \\
\hline 6. & Family Pressure & 25 & 30 & 45 & 50 & 50 \\
\hline
\end{tabular}




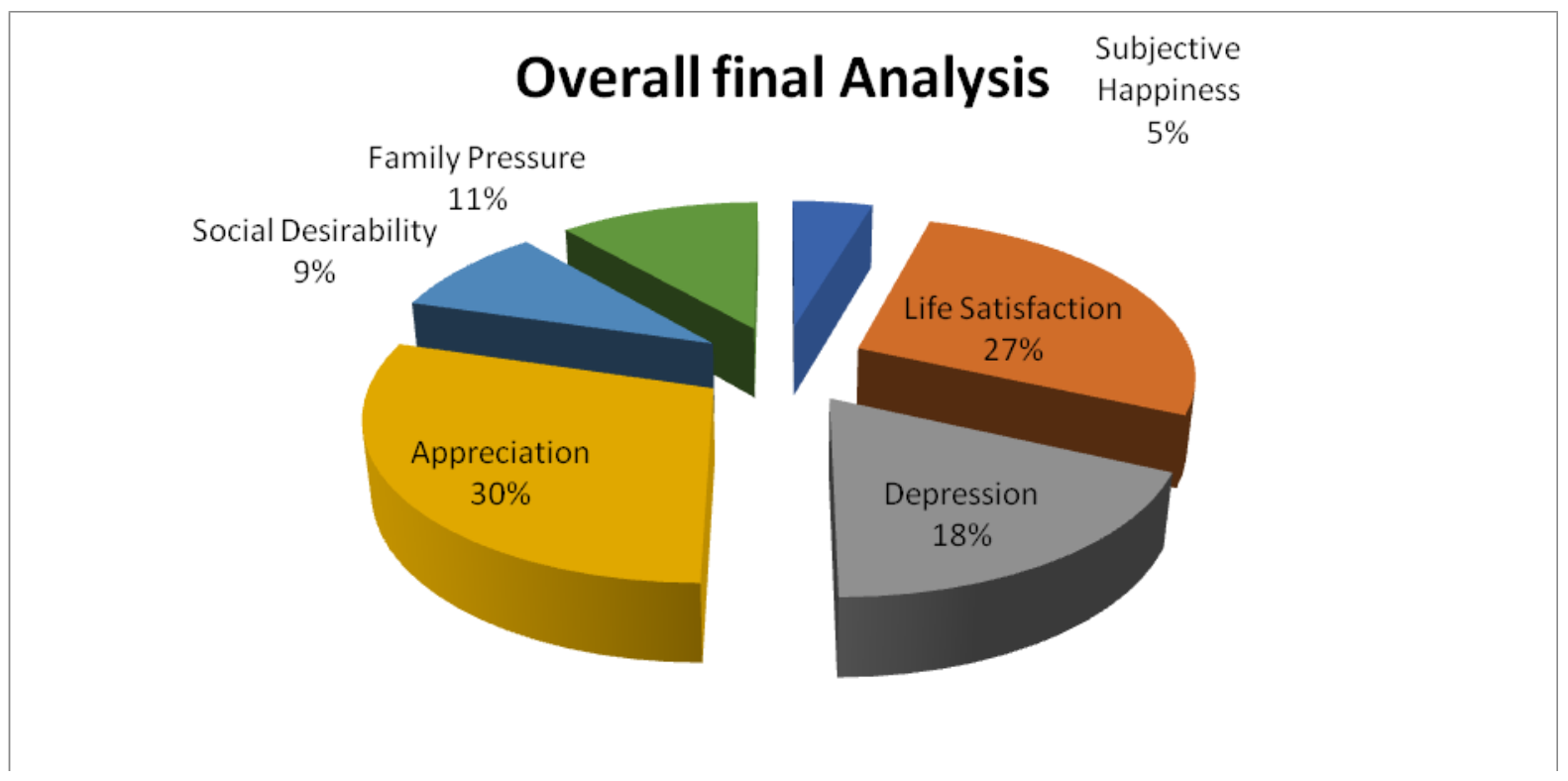

The scientists broke down their discoveries to make sense of how appreciation and life satisfaction has these impacts. They confirmed that appreciation completes four things:

1. Appreciation detaches us from poisonous, negative feelings and the ruminating that frequently goes with them. Composing a letter "moves our consideration" with the goal that our attention is on positive feelings.

2. Offering thanks encourages us regardless of whether we don't unequivocally impart it to somebody. We're more joyful and increasingly happy with life since we finished the activity.

3. The beneficial outcomes of appreciation composing compound like intrigue. You probably won't see the advantage of every day or week by week practice, yet following a little while and months, you will.

4. An appreciation practice prepares the mind to be more tuned in to encountering appreciation - a positive in addition to a positive, equivalent more positives.

In our analysis also it is clear that around 57\% males and females are having lack of appreciation and as a result they are not satisfied with the life.

\begin{tabular}{|c|cccccc|}
\hline S.No & \multicolumn{1}{|c|}{ Questions } & $\begin{array}{c}\text { Strongly } \\
\text { Disagree }\end{array}$ & Disagree & $\begin{array}{c}\text { Slightly } \\
\text { Agree }\end{array}$ & Agree & $\begin{array}{c}\text { Strongly } \\
\text { Agree }\end{array}$ \\
\hline 1. & Subjective Happiness & 5 & 40 & 5 & 20 & 30 \\
\hline 2. & Life Satisfaction & 30 & 15 & 22 & 28 & 5 \\
\hline 3. & Depression & 20 & 25 & 22 & 18 & 15 \\
\hline 4. & Appreciation & 23 & 22 & 23 & 17 & 15 \\
\hline
\end{tabular}




\begin{tabular}{|c|lccccc|}
\hline 5. & Social Desirability & 10 & 15 & 20 & 30 & 25 \\
\hline 6. & Family Pressure & 22 & 15 & 23 & 25 & 25 \\
\hline
\end{tabular}

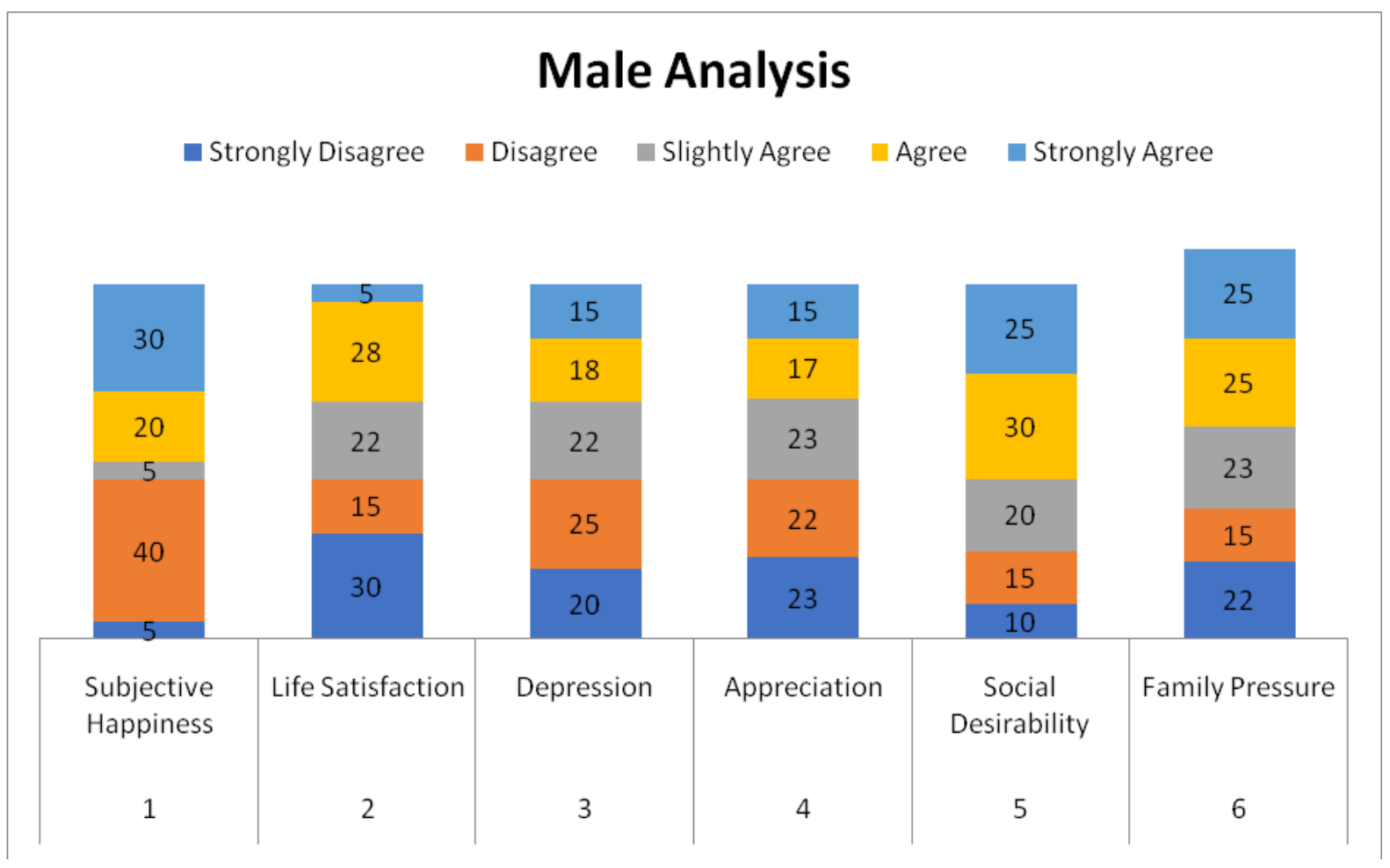

Here our analysis depicts about males happiness and why they are more educated.

\subsection{Do ladies truly feel that a lot more joyful than men?}

Gallup questioners additionally asked every respondent, "Did you experience the accompanying sentiments during a great deal of the day yesterday? What about...?" Despite their high generally life fulfillment, ladies were bound to state they felt the majority of the recorded negative emotions (torment, stress, pity, stress, outrage), and less inclined to state they felt all around refreshed or got the hang of something. Ladies were additionally bound to state they grinned or snickered, and to state they felt regarded, despite the fact that it's not clear by whom they felt regarded - by their kids, life partner, bosses at work, and so forth.

What this information proposes is that ladies' everyday lives incorporate progressively negative sentiments, yet they report higher satisfaction generally speaking. This could be extremely what's going on - any parent (or graduate understudy) comprehends taking on additional pressure or stress on the grounds that a youngster (or thesis) brings a more profound happiness. Yet, ladies are more terrible off from numerous points of view that we realize make individuals feel happy with their lives: they're less instructed, they have lower livelihoods, they have more awful self-revealed wellbeing, and they're bound to be separated or bereft. Also, ladies have less portrayal in many governments, face sexual orientation separation, and are all the more regularly casualties of individual viciousness.

Accordingly our examination additionally indicates why men's are increasingly taught on the grounds that they are free from family pressure, they got thankfulness for their work and their life is likewise social. 


\begin{tabular}{|c|lccccc|}
\hline S.No & \multicolumn{1}{|c}{ Questions } & $\begin{array}{c}\text { Final Analysis For Female } \\
\text { Strongly } \\
\text { Disagree }\end{array}$ & Disagree & $\begin{array}{c}\text { Slightly } \\
\text { Agree }\end{array}$ & Agree & $\begin{array}{c}\text { Strongly } \\
\text { Agree }\end{array}$ \\
\hline 1. & Subjective Happiness & 15 & 30 & 10 & 20 & 25 \\
\hline 2. & Life Satisfaction & 25 & 20 & 20 & 30 & 5 \\
\hline 3. & Depression & 18 & 27 & 25 & 15 & 15 \\
\hline 4. & Appreciation & 23 & 25 & 20 & 15 & 17 \\
\hline 5. & Social Desirability & 15 & 10 & 25 & 30 & 20 \\
\hline 6. & Family Pressure & 20 & 17 & 25 & 23 & 25 \\
\hline
\end{tabular}

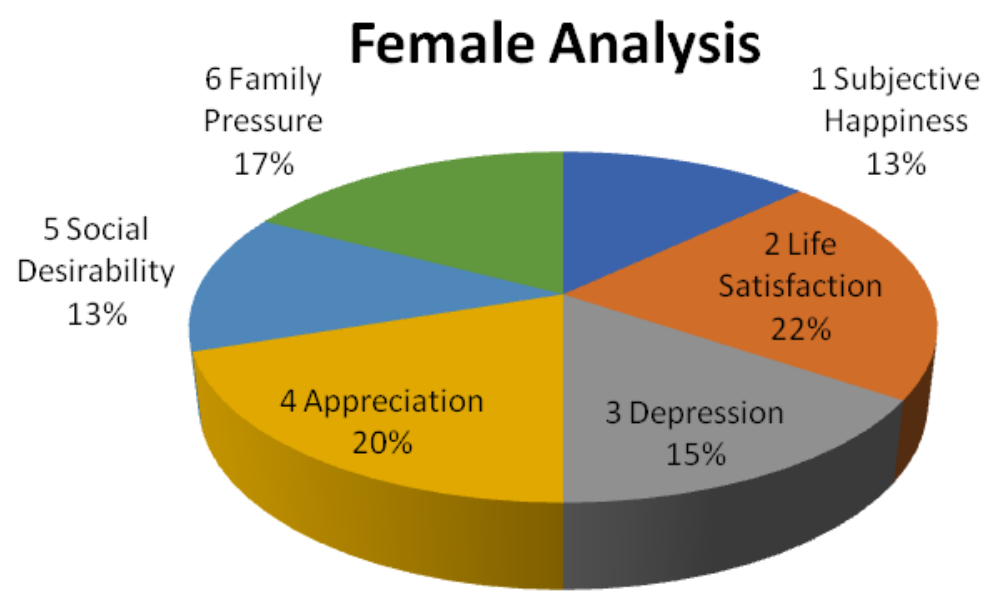

"Young ladies, it appears, are battling with these parts of their lives more than young men, now and again extensively so," said Prof Yvonne Kelly, from University College London, who drove the group behind the discoveries. [8]

\subsection{Sign up to the Media Briefing: news for the news-producers}

The outcomes provoked recharged worry about the quickly collecting proof that a lot more young ladies and young ladies display a scope of psychological wellness issues than young men and youngsters, and about the harm, these can cause, including self-hurt and selfdestructive contemplations.

The examination depends on meetings with right around 11,000 14-year-olds who are partaking in the Millennium Cohort Study, a noteworthy research venture into youngsters' lives. [8]

It found that numerous ladies invest undeniably more energy utilizing online life than young men, and furthermore that they are considerably more liable to show indications of wretchedness connected to their communication on stages, for example, Instagram, WhatsApp, and Facebook. [8] 
In our examination females in each segment, they are far backward when contrasted with men. Whai I understand from this "It's so natural to overlook the significance of genuine associations when we always have many individuals that we're attempting to intrigue readily available. I believe it's significant for youngsters to turn upward from their telephones and spotlight more on their general surroundings, and the stunning associations that they can make there."

\section{Conclusion}

Sexual orientation contrasts are one of the most exceptionally looked into points inside the instructive framework. Inside this article I will talk about the extending hole among sexual orientation and accomplishment, and attempt to clarify why these distinctions might be clear, and how to change them. The primary whole regions are:

- social improvement

- enthusiastic improvement

- connecting sounds and letters

- imaginative improvement

In end, there are numerous purposes behind scholastic gender orientation contrasts inside the training framework, including the generalizations and the perspectives on sex jobs inside society. So as to close the hole that is by all accounts ceaselessly developing, changing manners by which educating is drawn nearer is by all accounts a consistent arrangement. This incorporates the urging young men to peruse, as it has been proposed that because of an absence of perusing young men are kept down in their composition aptitudes. Changing the manners by which evaluation is completed, might be increasingly useful.

Just as fitting appraisals to suit the requirements of every gender orientation, particularly as young men appear to better in tests, particularly those that are various decision because of their temperament of hazard taking conduct (where as ladies are bound to exceed expectations in education). Another alternative is likewise permitting more involved and professional aspects onto the educational plan especially for females. So as to check whether these choices produce results, it is significant for specialists to stay up with the latest with the flow tasks of the instructive framework and continue completing their examination.

\section{References}

https://women-s.net/female-education-in-india/ https://populationmatters.org/the-facts/womensrights?gclid=EAIaIQobChMIjvyEnrrN5AIVi7HtCh0mzwD4EAAYASAAEgLmSvD_ BwE

Womens-Education-in-India-A-Situational-Analysis.pdf- Volume I Issue 4, January-March 2010

Sonalde Desai, Gender Inequalities and Demographic Behavior(book), Published in Population briefs: reports on Population Council research 
1995,https://www.semanticscholar.org/paper/Gender-inequalities-and-demographicbehavior.-Desai/70f3903e7af2c5d74400fc704181ed07948df884

http://www.bircu-journal.com/index.php/birle/article/view/349, Analysis the Role of

Headmaster in Applying Quality of Education in Primary School District, Aceh Barat http://www.biarjournal.com/index.php/biohs/article/view/12/11, Evaluation of Learning

Outcome: Comparative Education Unit Level Curriculum with the 2013 Curriculu inMTsN 1 Meda

Appreciation And Life Satisfaction: Does Appreciation Uniquely Predict Life Satisfaction

Above Gender, Coping Skills, Self-Esteem, And Positive Affectivity?, https://rucore.libraries.rutgers.edu/rutgers-lib/48180/PDF/1/play/

Depression in girls linked to higher use of social media,

https://www.theguardian.com/society/2019/jan/04/depression-in-girls-linked-to-higher-useof-social-media 